\title{
SETD2 wt Allele
}

National Cancer Institute

\section{Source}

National Cancer Institute. SETD2 wt Allele. NCI Thesaurus. Code C73663.

Human SETD2 is located in the vicinity of 3p21.31 and is approximately $108 \mathrm{~kb}$ in length.

This allele, which encodes histone-lysine N-methyltransferase SET D2 protein, may play a role in transcriptional activation and epigenetic modification of chromatin. 